\title{
Heavy Metal Contamination of Vegetables
}

\author{
Shobhana Ramteke1, Bharat Lal Sahu1, Nohar Singh Dahariya', Khageshwar Singh Patel', \\ Borislav Blazhev' ${ }^{2}$ Laurent Matini ${ }^{3}$ \\ ${ }^{1}$ School of Studies in Chemistry/Environmental Science, Pt. Ravishankar Shukla University, Raipur, India \\ ${ }^{2}$ Bulgarian Food Safety Agency, Central Laboratory for Chemical Testing and Control, Sofia, Bulgaria \\ ${ }^{3}$ Department of Exact Sciences, Marien Ngouabi University, Brazzaville, Congo \\ Email: patelkhageshwarsingh@gmail.com
}

Received 29 February 2016; accepted 3 June 2016; published 6 June 2016

Copyright (C) 2016 by authors and Scientific Research Publishing Inc.

This work is licensed under the Creative Commons Attribution International License (CC BY).

http://creativecommons.org/licenses/by/4.0/

c) (i) Open Access

\begin{abstract}
In India, several (>50) vegetables are widely used as food due to their high nutrition values. However, vegetables in industrial area are getting contaminated with heavy metals by disturbing biological and biochemical processes in the human body. In present study, the risk of human health by heavy metals (Fe, $\mathrm{As}, \mathrm{Cr}, \mathrm{Mn}, \mathrm{Cu}, \mathrm{Zn}, \mathrm{Pb}, \mathrm{Cd}$ and $\mathrm{Hg}$ ) through the intake of common vegetables i.e. Solanum lycopersicum, Solanum melongena, Amaranthus tricolor L., Chenopodium album L., Spinacia oleracea and Coriandrum sativum obtained from the largest coal burning basin, Korba, India is described . The concentration of $\mathrm{Fe}, \mathrm{As}, \mathrm{Cr}, \mathrm{Mn}, \mathrm{Cu}, \mathrm{Zn}, \mathrm{Cd}, \mathrm{Pb}$ and $\mathrm{Hg}$ in the soils (n =6) was ranged from 18,328 - 37,980, 85 - 105, $34-72,314-760,146-165,126-164,1.11-1.39,116-148$ and $0.11-0.21 \mathrm{mg} / \mathrm{kg}$ with mean value $(p=0.05)$ of $28,011 \pm 6582,96 \pm 6,57 \pm 11,597 \pm 148,153 \pm 5$, $145 \pm 11,1.26 \pm 0.10,133 \pm 11$ and $0.16 \pm 0.03 \mathrm{mg} / \mathrm{kg}$, respectively. The contamination, sources and bioaccumulation, pollution and health risk indices of the heavy metals i.e. As, $\mathrm{Fe}, \mathrm{Cr}, \mathrm{Mn}, \mathrm{Cu}, \mathrm{Zn}$, $\mathrm{Pb}, \mathrm{Cd}$ and $\mathrm{Hg}$ in the plants are described.
\end{abstract}

\section{Keywords}

Heavy Metals, Vegetables, Contamination, Metal Pollution Index, Health Risk Index

\section{Introduction}

Vegetables are common diet taken by populations throughout the world, being rich sources of essential nutrients, antioxidants and metabolites by acting as buffering agents for acidic substances produced during the digestion processes [1]. However, both essential and toxic elements were absorbed by vegetables from the soil [2]. Potential human health risks i.e. cancer, kidney damage, etc. from consumption of contaminated vegetables with the heavy metals (HMs) were reported [3]. The heavy metals i.e. $\mathrm{Cr}, \mathrm{Mn}, \mathrm{Fe}, \mathrm{Ni}, \mathrm{Cu}, \mathrm{Zn}, \mathrm{Cd}, \mathrm{Pb}$ and $\mathrm{Hg}$ were sig-

How to cite this paper: Ramteke, S., Sahu, B.L., Dahariya, N.S., Patel, K.S., Blazhev, B. and Matini, L. (2016) Heavy Metal Contamination of Leafy Vegetables. Journal of Environmental Protection, 7, 996-1004.

http://dx.doi.org/10.4236/jep.2016.77088 
nificantly accumulated in commonly used vegetables i.e. Amaranthus tricolor L., Chenopodium album L., Spinacia oleracea, Coriandrum sativum, Solanum lycopersicum and Solanum melongena [4]-[11]. In the present work, the contamination, enrichment, health risk and sources of the heavy metals i.e. $\mathrm{Fe}, \mathrm{As}, \mathrm{Cr}, \mathrm{Mn}, \mathrm{Cu}, \mathrm{Zn}, \mathrm{Pb}$, $\mathrm{Cd}$ and $\mathrm{Hg}$ in six vegetables (i.e. Solanum lycopersicum, Solanum melongena, Amaranthus tricolor L., Chenopodium album L., Spinacia oleracea and Coriandrum sativum) grown in soil of the largest coal basin: Korba city, Chhattisgarh, India are described.

\section{Materials and Methods}

\subsection{Collection of Vegetables}

The vegetables were collected from Urga area of Korba in January, 2013, Figure 1. Six commonly used

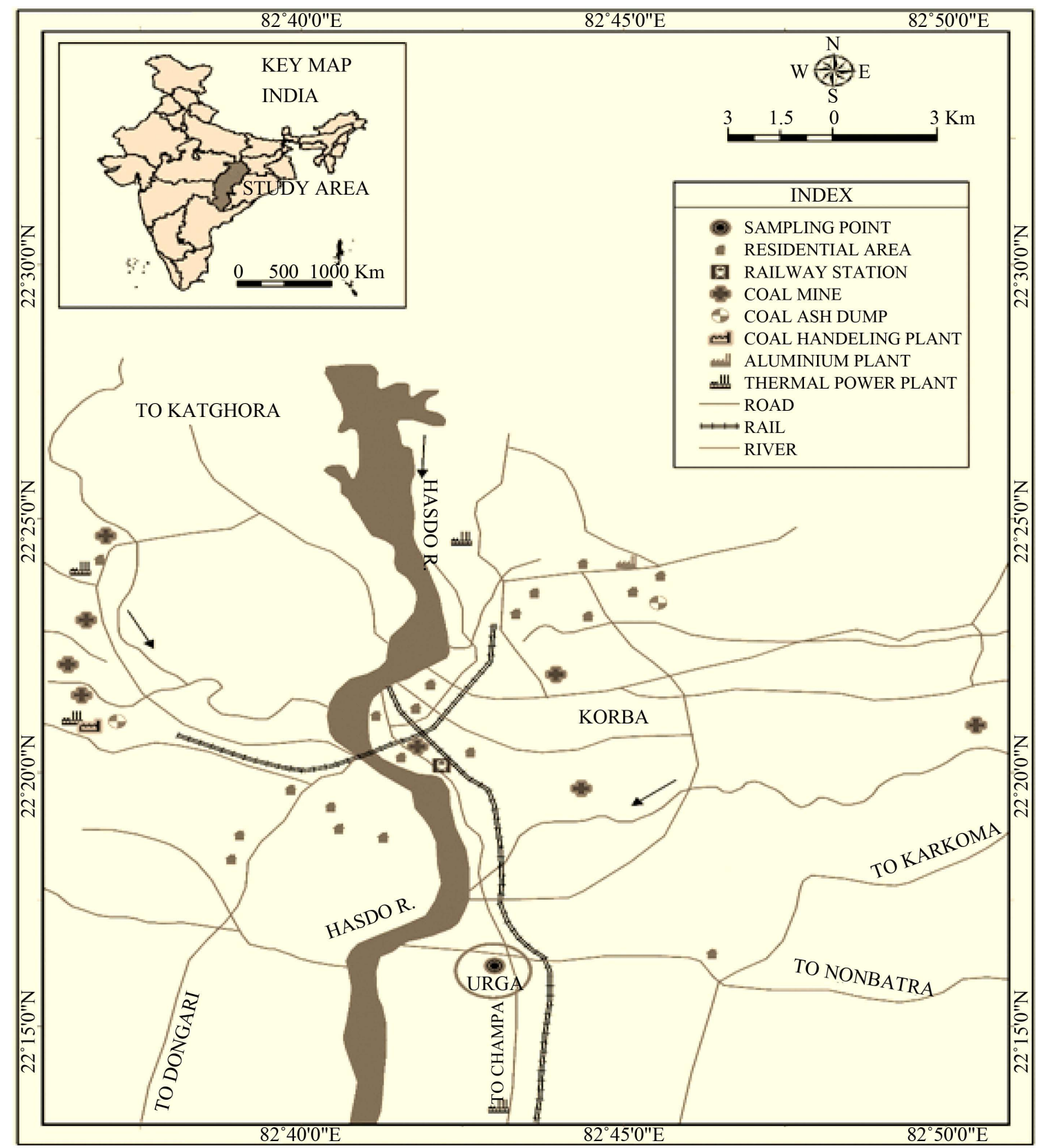

Figure 1. Representation of sampling location. 
vegetables (i.e. Solanum lycopersicum, Solanum melongena, Amaranthus tricolor L., Chenopodium album L., Spinacia oleracea and Coriandrum sativum) rich in nutrition and minerals were selected for analysis of the heavy metal loads [12]. The vegetables were harvested from the center and four corners of the plot. The vegetables were washed with deionised water to remove any possible foliar contaminants, such as pesticides, fertilisers, dust and mud. They were then cut into small pieces using a stainless steel knife and oven dried to remove moisture at $60^{\circ} \mathrm{C}$ to a constant mass. The dried tissue was stored in a moisture-free atmosphere prior to further processing. The samples were then ground using a ceramic mortar and pestle to reduce the dried material to a suitable size for digestion and analysis.

\subsection{Collection of Soil}

The soil samples (100 g) were collected with a stainless steel hand-trowel, within 0 - $20 \mathrm{~cm}$ depths from the rhizospheric area in January, 2013 [13]. The trowel was carefully cleaned after each sampling exercise, to avoid cross-contamination. The soil samples were kept in the polyethylene bottle and dried in an oven at $60^{\circ} \mathrm{C}$ for 12 hrs. The sample was milled and sieved out particles of $\leq 1 \mathrm{~mm}$ for the analysis.

\subsection{Analysis}

The P/T MARS CEM (Varian Company) microwave digester was used for the digestion of soil and plant samples at $200^{\circ} \mathrm{C}$ withhold time of $15 \mathrm{~min}$. The soil sample $(0.25 \mathrm{~g})$ was digested with aqua regia $\left(2 \mathrm{~mL} \mathrm{of} \mathrm{HNO}_{3}\right.$, $65 \%$, v/v $+6 \mathrm{~mL}$ of $\mathrm{HCl}, 37 \%$, v/v) by using EN 13346 method. The plant sample (0.25 g) was digested with 5 $\mathrm{mL} \mathrm{HNO}_{3}, 65 \%, \mathrm{v} / \mathrm{v}+2 \mathrm{~mL} \mathrm{H}_{2} \mathrm{O}_{2}$ by using EN 14084 method. The Varian Liberty AX Sequential ICP-AES (plasma flow: $15 \mathrm{~L} / \mathrm{min}$, auxiliary flow: $1.5 \mathrm{~L} / \mathrm{min}$, power: $1 \mathrm{KW}$, PMT voltage: $650 \mathrm{~V}$ ) was used for analysis of the metals i.e. $\mathrm{Cr}, \mathrm{Mn}, \mathrm{Fe}, \mathrm{Cu}$ and Zn. A VARIAN “SpectrAA 220Z” model graphite furnace atomic absorption spectrometer (GF-AAS) equipped with a longitudinal Zeeman effect background corrector was employed for analysis of metals i.e. $\mathrm{Cd}$ and $\mathrm{Pb}$. The VARIAN “SpectrAA 55B” equipped with hydride/cold vapor regenerator accessories was selected for analysis of elements i.e. As and Hg.

\subsection{Quality Control Analysis}

The standard soil (NCS DC73382, Spex Certiprep, UK) and apple leaf (NIST-1515, USA) reference materials were used for the quality control of the heavy metals. The accuracy of the results were found within $\leq \pm 2 \%$ of the certified value. The relative standard deviations of the triplicate analysis $(n=3)$ was $\leq \pm 6 \%$.

\subsection{Metal Pollution Index}

The Metal Pollution Index (MPI) is a geometrical mean of concentration of all tested metals in a given food stuff and computed by using following equation [14].

$$
\operatorname{MPI}(\mathrm{mg} / \mathrm{kg})=\left(C f_{1} \times C f_{2} \times C f_{3} \times \cdots \times C f_{n}\right)^{1 / n}
$$

where, $C f_{n}$ is a concentration of $n^{\text {th }}$ metal in a given food stuff.

\subsection{Health Risk Index}

The Health Risk Index (HRI) was computed as the ratio of estimated exposure of tested vegetables and oral reference dose by using following equation:

$$
\mathrm{HRI}=\mathrm{DIM} / \mathrm{R}_{\mathrm{f}} \mathrm{D}
$$

where, DIM and $\mathrm{R}_{\mathrm{f}} \mathrm{D}$ represent daily intake of metal and reference oral dose, respectively. The DIM was evaluated by using following equation:

$$
\mathrm{DIM}=C_{\text {metal }} \times C_{\text {factor }} \times D_{\text {f ood intake }} / B_{\text {average weigh }}
$$

where, $C_{\text {metal }}, C_{\text {factor }}, D_{\text {food intake }}$ and $B_{\text {average weight }}$ denote metal concentration in plant (mg/kg), conversion factor, daily intake of vegetable and average body mass of the consumers, respectively. The conversion factor of 0.085 was used to convert fresh vegetable weight to dry weight [15]. The average body of the consumers chosen was $60 \mathrm{~kg}$. The daily intake of vegetables i.e. Solanum lycopersicum, Solanum melongena, Amaranthus tricolor L., 
Chenopodium album L. and Spinacia oleracea was 300 g. However, daily intake of Coriandrum sativum was 100 g. The oral reference dose for $\mathrm{Hg}, \mathrm{As}, \mathrm{Cd}, \mathrm{Pb}, \mathrm{Cu}, \mathrm{Mn}, \mathrm{Zn}, \mathrm{Cr}$ and Fe reported was 0.0001, 0.0003, 0.001, $0.004,0.04,0.14,0.3,1.5$ and $15 \mathrm{mg} / \mathrm{kg} /$ day, respectively [16].

\section{Results \& Discussion}

\subsection{Heavy Metal Concentration in Soils}

Each soil sample was analyzed in triplicate, and the mean value of heavy metals i.e. Fe, $\mathrm{As}, \mathrm{Cr}, \mathrm{Mn}, \mathrm{Cu}, \mathrm{Zn}, \mathrm{Cd}$, $\mathrm{Pb}$ and $\mathrm{Hg}$ is presented in Table 1 . The concentration of $\mathrm{Fe}, \mathrm{As}, \mathrm{Cr}, \mathrm{Mn}, \mathrm{Cu}, \mathrm{Zn}, \mathrm{Cd}, \mathrm{Pb}$ and $\mathrm{Hg}$ in the rhizospheric soils $(n=6)$ was ranged from 18328 - 37980, 85 - 105, 34 - 72, $314-760,146$ - 165, 126 - 164, 1.11 1.39, $116-148$ and $0.11-0.21 \mathrm{mg} / \mathrm{kg}$ with mean value $(\mathrm{p}=0.05)$ of $28,011 \pm 6582,96 \pm 6,57 \pm 11,597 \pm 148$, $153 \pm 5,145 \pm 11,1.26 \pm 0.10,133 \pm 11$ and $0.16 \pm 0.03 \mathrm{mg} / \mathrm{kg}$, respectively. The background level of Al, Fe, $\mathrm{Mn}, \mathrm{Cr}, \mathrm{Cu}, \mathrm{Zn}, \mathrm{Cd}, \mathrm{Pb}$, As and $\mathrm{Hg}$ in the earth crust reported was 81,530, 39,200, 775, 92, 28, 67, 0.09, 17, 4.8 and $0.05 \mathrm{mg} / \mathrm{kg}$ [17]. The mean enrichment factor $\left(\mathrm{E}_{\mathrm{f}}\right)$ value with respect to $\mathrm{Al}$ for $\mathrm{Fe}, \mathrm{Mn}, \mathrm{Cr}, \mathrm{Cu}, \mathrm{Zn}, \mathrm{Cd}, \mathrm{Pb}$, As and $\mathrm{Hg}$ was found to be 1.0, 1.1, 0.8, 8.4, 2.9, 19, 11, 27 and 4.0, respectively. Three metals i.e. $\mathrm{Cd}, \mathrm{Pb}$ and As were enriched extremely in the soil of the studied area. The HMs concentration in the surface soil of the Korba basin was found to be higher than other coal burning regions of the country, probably due to higher exploitation of coals [18] [19].

\subsection{Heavy Metal Concentration in Vegetables}

Five species of each vegetable was analyzed, and their mean value at $95 \%$ confidence limit is summarized in Table 2. Solanum lycopersicum (tomato) is a staple common vegetable consumed by all classes of Indian citizens. Tomatoes are often a significant part of the human diet and are also abundant sources of antioxidants. The mean concentration value of $\mathrm{As}, \mathrm{Fe}, \mathrm{Cr}, \mathrm{Mn}, \mathrm{Cu}, \mathrm{Zn}, \mathrm{Cd}, \mathrm{Pb}$ and $\mathrm{Hg}(\mathrm{n}=5)$ was $0.56 \pm 0.06,500 \pm 23,2.9 \pm 0.6$, $71 \pm 11,25 \pm 8,29 \pm 10,0.42 \pm 0.11,1.1 \pm 0.4$ and $0.07 \pm 0.03 \mathrm{mg} / \mathrm{kg}$, respectively. The safe limits reported for As, Fe, Cr, Mn, Cu, Zn, Cd, Pb and $\mathrm{Hg}$ in the vegetables were 0.1, 425, 2.3, 500, 40, 100, 0.1, 0.2 and 0.03 $\mathrm{mg} / \mathrm{kg}$, respectively. The concentration of $\mathrm{As}, \mathrm{Cd}, \mathrm{Pb}$ and $\mathrm{Hg}$ was found to be higher than the safe limits. The content of metals i.e. $\mathrm{Cr}, \mathrm{Zn}, \mathrm{Cd}$ and $\mathrm{Cu}$ in the tomato of the studied area was observed to be comparable to the values reported in the Varanasi city, India [20]. Solanum melongena (Brinjal), an angiospermic family member of Solanaceae, is a common and popular vegetable crop grown in the subtropics and tropics, even in pollutant contaminated regions. The mean concentration value of $\mathrm{As}, \mathrm{Fe}, \mathrm{Cr}, \mathrm{Mn}, \mathrm{Cu}, \mathrm{Zn}, \mathrm{Cd}, \mathrm{Pb}$ and $\mathrm{Hg}(\mathrm{n}=5)$ was $0.78 \pm$ 0.09, $192 \pm 27,1.0 \pm 0.4,17 \pm 9,29 \pm 11,24 \pm 7,0.25 \pm 0.07,0.7 \pm 0.03$ and $0.08 \pm 0.04 \mathrm{mg} / \mathrm{kg}$, respectively. The concentration of four metals: $\mathrm{As}, \mathrm{Cd}, \mathrm{Pb}$ and $\mathrm{Hg}$ in the brinjal was found to be higher than the safe limits. The content of $\mathrm{Fe}, \mathrm{Mn}, \mathrm{Cu}$ and $\mathrm{Zn}$ in the brinjal of the studied area was found to be comparable the values reported in the other parts of country [21] [22].

Amaranthus species are cultivated and consumed as leafy vegetables in many parts of the world. Amaranthus are excellent raw in salads, used as a steamed vegetable, and included in soups and stews. The mean concentration value of $\mathrm{As}, \mathrm{Fe}, \mathrm{Cr}, \mathrm{Mn}, \mathrm{Cu}, \mathrm{Zn}, \mathrm{Cd}, \mathrm{Pb}$ and $\mathrm{Hg}(\mathrm{n}=5)$ was found to be $2.08 \pm 0.22,2255 \pm 116,10 \pm 3$, $200 \pm 16,36 \pm 4,106 \pm 15,0.67 \pm 0.11,0.7 \pm 0.04$ and $0.14 \pm 0.05 \mathrm{mg} / \mathrm{kg}$, respectively. The content of six metals i.e. As, Fe, $\mathrm{Cr}, \mathrm{Cd}, \mathrm{Pb}$ and $\mathrm{Hg}$ was found higher than the safe limit of $0.1,425,2.3,0.1,0.2$ and $0.03 \mathrm{mg} / \mathrm{kg}$,

Table 1. Mean value $(\mathrm{n}=5)$ of heavy metal content in rhizospheric soil, $\mathrm{mg} / \mathrm{kg}$.

\begin{tabular}{ccccccccccc}
\hline S. No. & Sample No. & $\mathrm{Fe}$ & $\mathrm{As}$ & $\mathrm{Cr}$ & $\mathrm{Mn}$ & $\mathrm{Cu}$ & $\mathrm{Zn}$ & $\mathrm{Cd}$ & $\mathrm{Pb}$ & $\mathrm{Hg}$ \\
\hline 1 & $\mathrm{~S} 1$ & $24,235 \pm 1020$ & $103 \pm 11$ & $49 \pm 6$ & $712 \pm 58$ & $165 \pm 9$ & $159 \pm 8$ & $1.11 \pm 0.09$ & $147 \pm 10$ & $0.21 \pm 0.4$ \\
2 & $\mathrm{~S} 2$ & $33,865 \pm 1424$ & $98 \pm 9$ & $59 \pm 7$ & $749 \pm 62$ & $150 \pm 8$ & $136 \pm 7$ & $1.31 \pm 0.10$ & $136 \pm 9$ & $0.17 \pm 0.03$ \\
3 & $\mathrm{~S} 3$ & $33,678 \pm 1437$ & $105 \pm 12$ & $62 \pm 8$ & $618 \pm 52$ & $146 \pm 7$ & $140 \pm 6$ & $1.39 \pm 0.11$ & $133 \pm 8$ & $0.11 \pm 0.02$ \\
4 & $\mathrm{~S} 4$ & $19,980 \pm 946$ & $85 \pm 8$ & $67 \pm 8$ & $428 \pm 46$ & $153 \pm 9$ & $164 \pm 7$ & $1.23 \pm 0.12$ & $116 \pm 7$ & $0.19 \pm 0.03$ \\
5 & $\mathrm{~S} 5$ & $37,980 \pm 1547$ & $91 \pm 7$ & $72 \pm 9$ & $760 \pm 65$ & $156 \pm 8$ & $144 \pm 6$ & $1.38 \pm 0.13$ & $148 \pm 10$ & $0.14 \pm 0.03$ \\
6 & $\mathrm{~S} 6$ & $18,328 \pm 878$ & $93 \pm 6$ & $34 \pm 5$ & $314 \pm 34$ & $149 \pm 7$ & $126 \pm 6$ & $1.13 \pm 0.11$ & $119 \pm 8$ & $0.12 \pm 0.02$ \\
\hline
\end{tabular}

$\mathrm{S}=$ Soil sample. 
Table 2. Mean value $(\mathrm{n}=5)$ of heavy metal content in dried vegetable, $\mathrm{mg} / \mathrm{kg}$.

\begin{tabular}{ccccccccccc}
\hline S. No. & Vegetable & As & $\mathrm{Fe}$ & $\mathrm{Cr}$ & $\mathrm{Mn}$ & $\mathrm{Cu}$ & $\mathrm{Zn}$ & $\mathrm{Cd}$ & $\mathrm{Pb}$ & $\mathrm{Hg}$ \\
\hline V1 & SL & $0.56 \pm 0.06$ & $500 \pm 23$ & $2.9 \pm 0.6$ & $71 \pm 11$ & $25 \pm 8$ & $29 \pm 10$ & $0.42 \pm 0.11$ & $1.1 \pm 0.4$ & $0.07 \pm 0.03$ \\
V2 & SML & $0.78 \pm 0.09$ & $192 \pm 27$ & $1.0 \pm 0.4$ & $17 \pm 9$ & $29 \pm 11$ & $24 \pm 7$ & $0.25 \pm 0.07$ & $0.7 \pm 0.03$ & $0.08 \pm 0.04$ \\
V3 & ATL & $2.08 \pm 0.22$ & $2255 \pm 116$ & $10 \pm 3$ & $200 \pm 16$ & $36 \pm 4$ & $106 \pm 15$ & $0.67 \pm 0.11$ & $0.7 \pm 0.04$ & $0.14 \pm 0.05$ \\
V4 & CAL & $1.86 \pm 0.24$ & $1985 \pm 97$ & $17 \pm 5$ & $213 \pm 18$ & $46 \pm 6$ & $118 \pm 13$ & $1.57 \pm 0.23$ & $2.3 \pm 0.2$ & $0.18 \pm 0.05$ \\
V5 & SO & $1.99 \pm 0.22$ & $1406 \pm 65$ & $8.0 \pm 2.1$ & $676 \pm 34$ & $62 \pm 8$ & $98 \pm 10$ & $1.46 \pm 0.19$ & $4.7 \pm 0.4$ & $0.12 \pm 0.04$ \\
V6 & CS & $2.05 \pm 0.31$ & $1618 \pm 71$ & $7.6 \pm 1.8$ & $59 \pm 7$ & $71 \pm 9$ & $121 \pm 11$ & $0.75 \pm 0.09$ & $1.8 \pm 0.2$ & $0.14 \pm 0.05$ \\
\hline
\end{tabular}

$\mathrm{SL}=$ Solanum lycopersicum, $\mathrm{SML}=$ Solanum melongena $\mathrm{L} ., \mathrm{ATL}=$ Amaranthus tricolor L., CAL = Chenopodium album L., SO = Spinacia oleracea, $\mathrm{CS}=$ Coriandrum sativum .

respectively. The $\mathrm{Zn}, \mathrm{Cd}$ and $\mathrm{Pb}$ content in the Amaranthus leaves of the studied area was found to be comparable to the values reported in African and Bangladesh Amaranthus leaves [6] [7]. The high content of $\mathrm{Pb}$ (5.75 $\mathrm{mg} / \mathrm{kg}$ ) in the Amaranthus leaves grown in Lagos was reported [11]. Chenopodium album L. is cultivated as a food crop in Asia and parts of Africa. Especially in India, it has major cultivations and is eaten as a leafy vegetable like many others. The mean concentration value $(\mathrm{n}=5)$ of $\mathrm{As}, \mathrm{Fe}, \mathrm{Cr}, \mathrm{Mn}, \mathrm{Cu}, \mathrm{Zn}, \mathrm{Cd}, \mathrm{Pb}$ and $\mathrm{Hg}$ was found to be $1.86 \pm 0.24,1985 \pm 97,17 \pm 5,213 \pm 18,46 \pm 6,118 \pm 13,1.57 \pm 0.23,2.3 \pm 0.2$ and $0.18 \pm 0.05$ $\mathrm{mg} / \mathrm{kg}$. The content of all metals except Mn was found higher than reported safe limits. The Chenopodium album L. was reported as phytoextractants for metals i.e. $\mathrm{Cr}, \mathrm{Mn}, \mathrm{Fe}, \mathrm{Cu}, \mathrm{Zn}, \mathrm{Cd}$ and $\mathrm{Pb}$ from the contaminated soils [4] [23]. In the present work, the Chenopodium album L. was found to be as good phytoextracting plant for the metals i.e. As, Fe, Cr, Mn, Cu, Zn, Cd, Pb and Hg. Spinach (Spinacia oleracea) is one of widely used as leafy vegetable rich in nutrients, antioxidants and anticancer constituents. The high loading of As, Fe, Cr, Mn, $\mathrm{Cu}, \mathrm{Zn}, \mathrm{Cd}, \mathrm{Pb}$ and $\mathrm{Hg}$ was marked with mean value of $1.99 \pm 0.22,1406 \pm 65,8.0 \pm 2.1,676 \pm 34,62 \pm 8,98 \pm$ $10,1.46 \pm 0.19,4.7 \pm 0.4$ and $0.12 \pm 0.04 \mathrm{mg} / \mathrm{kg}$, respectively. All metals (except $\mathrm{Zn}$ ) were strongly accumulated in the Spinacia oleracea by crossing the safe limits. The $\mathrm{Cu}, \mathrm{Cd}$ and $\mathrm{Pb}$ contents observed in the Spinacia leaves of the studied area was found to be comparable the values reported in the leaves of the Bangalore, Delhi and Bangladesh regions [6] [10] [24].

The Coriandrum sativum has a very strong aroma with rich in nutrients, vitamins and antibacterial chemicals. The fresh leaves of Coriandrum sativum are widely used an ingredient in Indian foods. The mean concentration value of $\mathrm{As}, \mathrm{Fe}, \mathrm{Cr}, \mathrm{Mn}, \mathrm{Cu}, \mathrm{Zn}, \mathrm{Cd}, \mathrm{Pb}$ and $\mathrm{Hg}(\mathrm{n}=5)$ was $2.05 \pm 0.31,1618 \pm 71,7.6 \pm 1.8,59 \pm 7,71 \pm 9$, $121 \pm 11,0.75 \pm 0.09,1.8 \pm 0.2$ and $0.14 \pm 0.05 \mathrm{mg} / \mathrm{kg}$, respectively. The As content in the Coriandrum sativum leaves of the studied area was found to be higher than the value reported in the coriander leaves of the West Bengal [5]. The content of other metals i.e. $\mathrm{Cu}, \mathrm{Zn}, \mathrm{Cd}$ and $\mathrm{Pb}$ in the leave of studied area was found to be comparable to the values reported in the leaves of Bangalore city and Bangladesh [6] [24].

\subsection{Bioaccumulation Index of Metals}

The bioaccumulation index (BI) is a ratio of vegetable to soil content of the metal. Significant BI values $(>0.8)$ of the Mn and Cd with Spinacia oleracea, $\mathrm{Zn}$ and $\mathrm{Hg}$ with Coriandrum sativum, Hg with Amaranthus tricolor L. and $\mathrm{Cd}$ and $\mathrm{Hg}$ with Chenopodium album L. were recorded, may be due to coordination of the metals with the biomass oxalates [25].

\subsection{Metal Pollution Index}

The metal pollution index (MPI) for As, Fe, Cr, Mn, $\mathrm{Cu}, \mathrm{Zn}, \mathrm{Cd}, \mathrm{Pb}$ and $\mathrm{Hg}$ in Solanum lycopersicum, Solanum melongena, Amaranthus tricolor L., Chenopodium album L., Spinacia oleracea and Coriandrum sativum was found to be 4.8, 3.1, 11.0, 15.0, 16.2 and $11.0 \mathrm{mg} / \mathrm{kg}$, respectively. The several folds higher MPI value for the leafy vegetables was marked, may be due to their higher biomass production as shown in Figure 2.

\subsection{Health Risk Index}

The daily intake of metals (DIM) is shown in Table 3. The DIM value As, Fe, Cr, $\mathrm{Mn}, \mathrm{Cu}, \mathrm{Zn}, \mathrm{Cd}, \mathrm{Pb}$ and $\mathrm{Hg}$ 
for six vegetables was ranged from 0.24 - 0.88, 82 - 958, 0.4 - 7.2, 7 - 287, 11 - 26, 10 - 50, 0.11 - 0.67, 0.26 2.00 and $0.030-0.077 \mathrm{mg} / \mathrm{g} / \mathrm{day} /$ person, respectively. The remarkably high DIM value of four metals i.e. Fe, $\mathrm{Mn}, \mathrm{Cu}$ and $\mathrm{Zn}$ for all vegetables was observed. Among them, the highest DIM value for metals i.e. As, Fe, $\mathrm{Cr}$, $\mathrm{Zn}, \mathrm{Pb}$ and $\mathrm{Hg}$ with the Amaranthus tricolor L. was marked as shown in Figure 3. The HRI values of metals in the vegetables are summarized in Table 4 . The extremely high HRI value of As $(>500)$ with all vegetables was recorded. The highest HRI value of metals i.e. As, $\mathrm{Mn}, \mathrm{Cu}, \mathrm{Cd}, \mathrm{Pb}$ and $\mathrm{Hg}$ with the Spinacia oleracea was observed due to higher $\mathrm{Cd}$ and $\mathrm{Pb}$ contents, Figure 4.

\subsection{Factor Analysis}

The results of FA gave two factors accounted for $92.86 \%$ of the total variance (Table 5). Factor-I accounted for $71.51 \%$ of the total variance. It explained more than the half of the total variance, and is positively correlated with $\mathrm{Cr}, \mathrm{Fe}, \mathrm{Zn}, \mathrm{Hg}$ and As (Table 6). Factor-1 could characterize the behavior of the above-mentioned HMs in the relation to oxides/oxyhydroxides of Fe. Factor-II was positively correlated with Cd, Mn and Pb, (Table 6). This factor may be termed as the association of Mn oxides with $\mathrm{Cd}$ and $\mathrm{Pb}$.

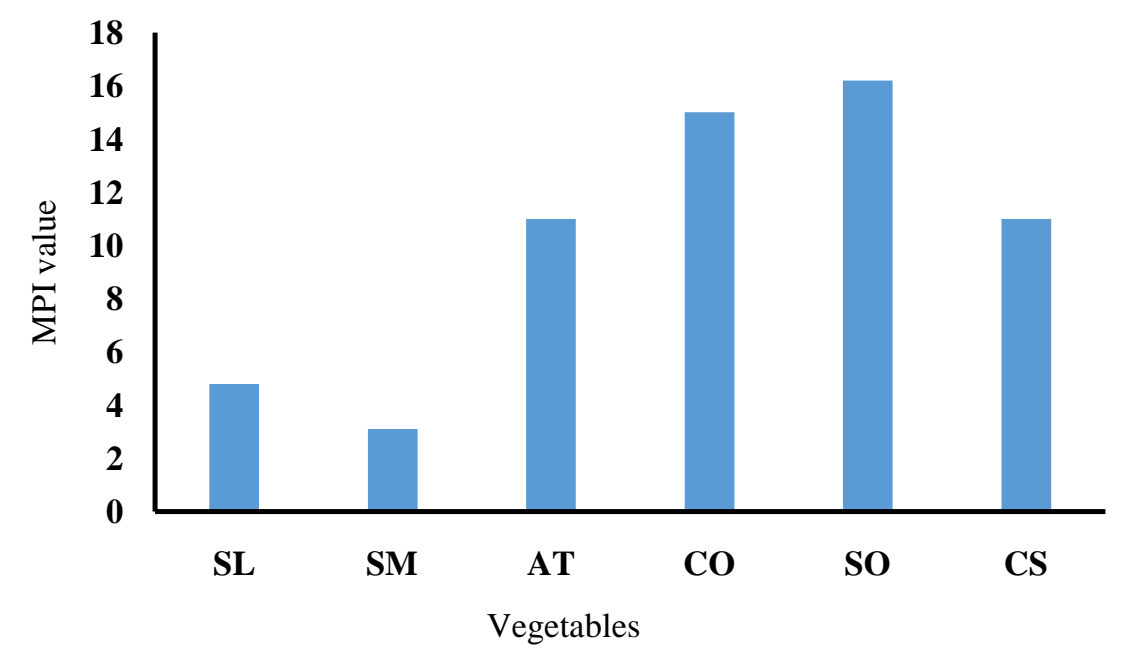

Figure 2. Metal pollution index in vegetables. SL = Solanum lycopersicum, $\mathrm{SM}=$ Solanum melongena, $\mathrm{AT}=$ Amaranthus tricolor, $\mathrm{SO}=$ Spinacia oleracea, $\mathrm{CS}=$ Coriandrum sativum.

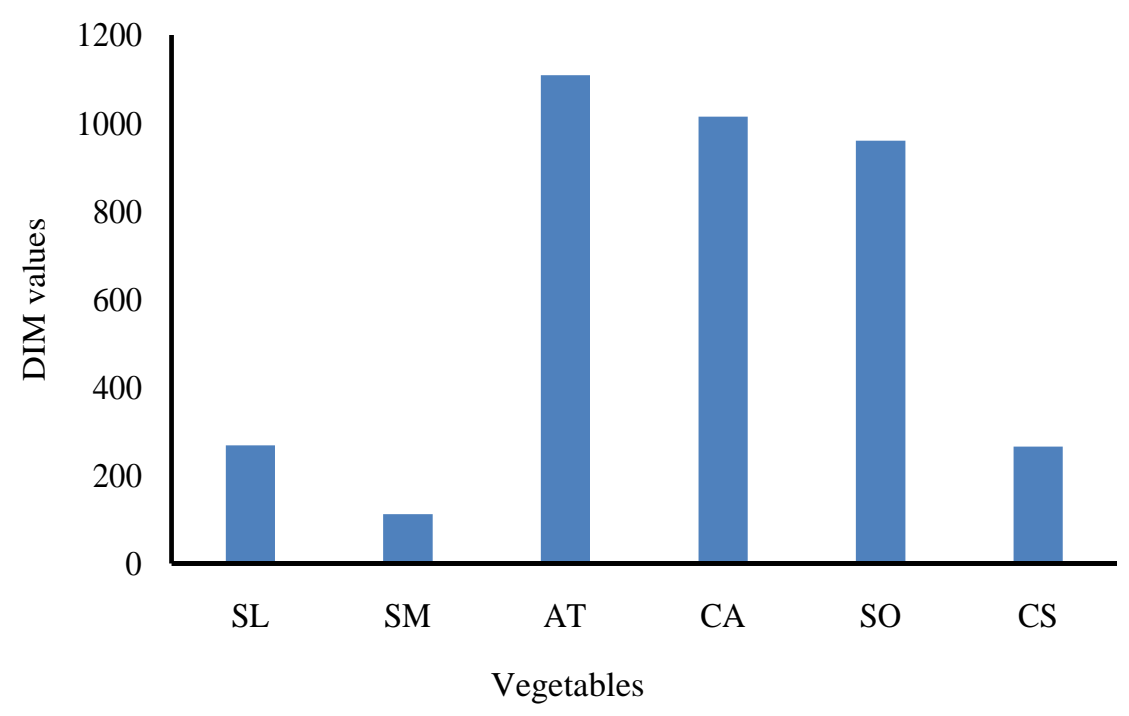

Figure 3. The DIM value for various vegetables. 


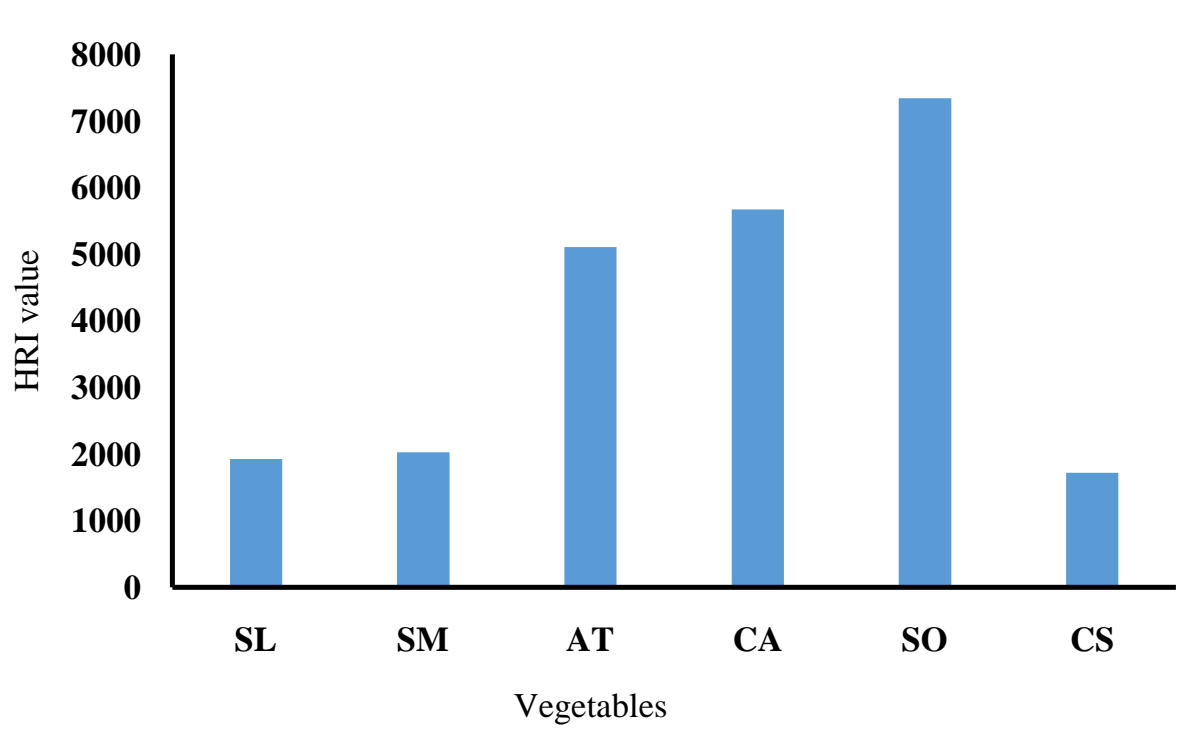

Figure 4. HRI value of vegetables for nine metals: $\mathrm{As}, \mathrm{Fe}, \mathrm{Cr}, \mathrm{Mn}, \mathrm{Cu}, \mathrm{Zn}, \mathrm{Cd}, \mathrm{Pb}$ and $\mathrm{Hg}$.

Table 3. Daily intake of metals, mg/g/day/person.

\begin{tabular}{cccccccccccc}
\hline Vegetable & $\mathrm{As}$ & $\mathrm{Fe}$ & $\mathrm{Cr}$ & $\mathrm{Mn}$ & $\mathrm{Cu}$ & $\mathrm{Zn}$ & $\mathrm{Cd}$ & $\mathrm{Pb}$ & $\mathrm{Hg}$ \\
\hline S. lycopersicum & 0.24 & 213 & 1.2 & 30 & 11 & 12 & 0.18 & 0.47 & 0.030 \\
S. melongena & 0.33 & 82 & 0.4 & 7 & 12 & 10 & 0.11 & 0.30 & 0.034 \\
Amaranthus tricolor L. & 0.88 & 958 & 4.3 & 85 & 15 & 45 & 0.28 & 0.30 & 0.060 \\
Chenopodium album L. & 0.79 & 844 & 7.2 & 91 & 20 & 50 & 0.67 & 0.98 & 0.077 \\
Spinacia oleracea & 0.85 & 598 & 3.4 & 287 & 26 & 42 & 0.62 & 2.00 & 0.051 \\
C. sativum & 0.29 & 229 & 1.1 & 8 & 10 & 17 & 0.11 & 0.26 & 0.020 \\
\hline
\end{tabular}

Table 4. Health risk index of metals.

\begin{tabular}{|c|c|c|c|c|c|c|c|c|c|}
\hline Vegetable & As & $\mathrm{Fe}$ & $\mathrm{Cr}$ & $\mathrm{Mn}$ & $\mathrm{Cu}$ & $\mathrm{Zn}$ & $\mathrm{Cd}$ & $\mathrm{Pb}$ & $\mathrm{Hg}$ \\
\hline S. lycopersicum & 793 & 14 & 0.8 & 216 & 266 & 41 & 179 & 117 & 298 \\
\hline S. melongena & 1105 & 5 & 0.3 & 52 & 308 & 34 & 106 & 74 & 340 \\
\hline Amaranthus tricolor L. & 2947 & 64 & 2.8 & 607 & 383 & 150 & 285 & 74 & 595 \\
\hline Chenopodium album L. & 2635 & 56 & 4.8 & 647 & 489 & 167 & 667 & 244 & 765 \\
\hline Spinacia oleracea & 2819 & 40 & 2.3 & 2052 & 659 & 139 & 621 & 499 & 510 \\
\hline C. sativum & 968 & 15 & 0.7 & 60 & 251 & 57 & 106 & 64 & 198 \\
\hline
\end{tabular}

\section{Conclusion}

The soil in the studied area was extremely contaminated with toxic metals i.e. As, $\mathrm{Pb}$ and $\mathrm{Hg}$. They were accumulated in the vegetables, and their prolonged consumption may disturb the biological and biochemical processes in the humans. The significant BI value of metals i.e. $\mathrm{Mn}, \mathrm{Zn}, \mathrm{Cd}$ and $\mathrm{Hg}$ with the leafy vegetables was observed. Among them, the highest MPI value for the metals with Spinacia oleracea was recorded which may be due to the higher biomass production. The extremely high HRI value for As in all tested vegetables was observed. The detailed investigation of the MPI value for various types of leafy vegetables grown in the studied area is urgently required for mapping of the human health hazards in local people. 
Table 5. Results of factor analysis of heavy metals in the vegetables.

\begin{tabular}{ccc}
\hline Variable & Factor-I & Factor-II \\
\hline $\mathrm{Cd}$ & 0.41 & $\mathbf{0 . 9 1}$ \\
$\mathrm{Cr}$ & $\mathbf{0 . 9 2}$ & 0.28 \\
$\mathrm{Cu}$ & 0.61 & 0.55 \\
$\mathrm{Fe}$ & $\mathbf{0 . 9 6}$ & 0.10 \\
$\mathrm{Mn}$ & 0.18 & $\mathbf{0 . 9 3}$ \\
$\mathrm{Pb}$ & 0.10 & $\mathbf{0 . 9 9}$ \\
$\mathrm{Zn}$ & $\mathbf{0 . 9 5}$ & 0.28 \\
$\mathrm{Hg}$ & $\mathbf{0 . 9 6}$ & 0.21 \\
$\mathrm{As}$ & $\mathbf{0 . 9 6}$ & 0.26 \\
Eigenvalue & 6.44 & 1.92 \\
\%Variance & 71.51 & 21.35 \\
\hline \%umulative variance & 71.51 & 92.86 \\
\hline
\end{tabular}

Loading value $>0.70$, significant at $\mathrm{p}<0.05$.

Table 6. Correlation matrix of heavy metals.

\begin{tabular}{|c|c|c|c|c|c|c|c|c|c|}
\hline & As & $\mathrm{Fe}$ & $\mathrm{Cr}$ & $\mathrm{Mn}$ & $\mathrm{Cu}$ & $\mathrm{Zn}$ & $\mathrm{Cd}$ & $\mathrm{Pb}$ & $\mathrm{Hg}$ \\
\hline As & 1 & & & & & & & & \\
\hline $\mathrm{Fe}$ & 0.91 & 1 & & & & & & & \\
\hline $\mathrm{Cr}$ & 0.72 & 0.86 & 1 & & & & & & \\
\hline $\mathrm{Mn}$ & 0.49 & 0.32 & 0.31 & 1 & & & & & \\
\hline $\mathrm{Cu}$ & 0.75 & 0.47 & 0.37 & 0.44 & 1 & & & & \\
\hline $\mathrm{Zn}$ & 0.96 & 0.93 & 0.83 & 0.37 & 0.76 & 1 & & & \\
\hline $\mathrm{Cd}$ & 0.66 & 0.61 & 0.82 & 0.72 & 0.56 & 0.71 & 1 & & \\
\hline $\mathrm{Pb}$ & 0.45 & 0.22 & 0.32 & 0.91 & 0.65 & 0.41 & 0.80 & 1 & \\
\hline $\mathrm{Hg}$ & 0.84 & 0.89 & 0.95 & 0.23 & 0.54 & 0.92 & 0.74 & 0.28 & 1 \\
\hline
\end{tabular}

\section{Acknowledgements}

One of the author, SR is grateful to the UGC, New Delhi for the award of the RG national fellowship.

\section{References}

[1] Li, T.S.C. (2008) Vegetables and Fruits: Nutritional and Therapeutic Values. CRC Press, Boca Raton. http://dx.doi.org/10.1201/9781420068733

[2] Hajeb, P., Sloth, J.J., Shakibazadeh, S., Mahyudin, N.A. and Afsah-Hejri, L. (2014) Toxic Elements in Food: Occurrence, Binding and Reduction Approaches. Comprehensive Reviews in Food Science and Food Safety, 13, 457-472. http://dx.doi.org/10.1111/1541-4337.12068

[3] Zhuang, P., McBride, M.B., Xia, H., Li, N. and Li, Z. (2009) Health Risk from Heavy Metals via Consumption of Food Crops in the Vicinity of Dabaoshan Mine, South China. Science of the Total Environment, 407, 1551-1561. http://dx.doi.org/10.1016/j.scitotenv.2008.10.061

[4] Gupta, A.K. and Sinha, S. (2007) Phytoextraction Capacity of the Chenopodium album L. Grown on Soil Amended with Tannery Sludge. Bioresource Technology, 98, 442-446. http://dx.doi.org/10.1016/j.biortech.2006.01.015

[5] Kundu, R., Bhattacharyya, K. and Pal, S. (2012) Arsenic Intake and Dietary Risk Assessment of Coriander (Coriandrum sativum L.) Leaves in the Gangetic Basin of West Bengal. Journal of Spices and Aromatic Crops, 21,125-129. 
[6] Naser, H.M., Sultana, S., Mahmud, N.U., Gomes, R. and Noor, S. (2011) Heavy Metal Levels in Vegetables with Growth Stage and Plant Species Variations. Bangladesh Journal of Agricultural Research, 36, 563-574.

[7] Oluwatosin, G.A., Adeoyolanu, O.D., Ojo, A.O., Are, K.S., Dauda, T.O. and Aduramigba-Modupe, V.O. (2010) Heavy Metal Uptake and Accumulation by Edible Leafy Vegetable (Amaranthus hybridus L.) Grown on Urban Valley Bottom Soils in Southwestern Nigeria. Soil and Sediment Contamination, 19, 1-20. http://dx.doi.org/10.1080/15320380903252911

[8] Pathak, C., Chopra, A.K. and Srivastava, S. (2013) Accumulation of Heavy Metals in Spinacia oleracea Irrigated with Paper Mill Effluent and Sewage. Environment Monitoring and Assessment, 185, 7343-7352. http://dx.doi.org/10.1007/s10661-013-3104-8

[9] Swati, N., Srivastava, R.C. and Agarwal, K.M. (2012) Accumulation of Heavy Metals by Solanum melonuma Irrigated with Wastewater. International Journal of Agriculture Environment and Biotechnology, 5, 329-332.

[10] Singh, S. and Kumar, M. (2006) Heavy Metal Load of Soil, Water and Vegetables in Peri-Urban Delhi. Environmental Monitoring and Assessment, 120, 79-91. http://dx.doi.org/10.1007/s10661-005-9050-3

[11] Yusuf, K.A. and Oluwole, S.O. (2009) Heavy Metal (Cu, Zn, Pb) Contamination of Vegetables in Urban City: A Case Study in Lagos. Research Journal of Environmental Sciences, 3, 292-298. http://dx.doi.org/10.3923/rjes.2009.292.298

[12] Kalra, Y.P. (1998) Handbook of Reference Methods for Plant Analysis. CRC Press, Boca Raton.

[13] Tan, K.H. (2005) Soil, Sampling, Preparation and Analysis. 2nd Edition, CRC Press, Boca Raton.

[14] Usero, J., Gonzalez-Regalado, E. and Gracia, I. (1997) Trace Metals in Bivalve Mollusks Ruditapes decussates and Ruditapes philippinarum from the Atlantic Coast of Southern Spain. Environment International, 23, 291-298. http://dx.doi.org/10.1016/S0160-4120(97)00030-5

[15] Rattan, R.K., Datta, S.P., Chhonkar, P.K., Suribabu, K. and Singh, A.K. (2005) Long-Term Impact of Irrigation with Sewage Effluents on Heavy Metals content in Soils, Crops and Groundwater: A Case Study. Agriculture Ecosystem Environment, 109, 310-322. http://dx.doi.org/10.1016/j.agee.2005.02.025

[16] EPA (1997) Exposure Factors Handbook—General Factors. EPA/600/P-95/002Fa, Vol. I, Office of Research and Development. National Centre for Environmental Assessment. US Environmental Protection Agency, Washington DC.

[17] Rudnick, R.L. and Gao, S. (2003) Composition of the Continental Crust. In: Rudnick, R.L., Holland, H.D. and Turekian, K.K., Eds., The Crust: Treatise on Geochemistry, Vol. 3, Elsevier-Pergamum, Oxford, 1-64. http://dx.doi.org/10.1016/b0-08-043751-6/03016-4

[18] Agrawal, P., Mittal, A., Prakash, R., Kumar, M., Singh, T.B. and Tripathi, S.K. (2010) Assessment of Contamination of Soil Due to Heavy Metals around Coal Fired Thermal Power Plants at Singrauli Region of India. Bulletin of Environmental Contamination and Toxicology, 85, 219-223. http://dx.doi.org/10.1007/s00128-010-0043-8

[19] Sengupta, S., Chatterjee, T., Ghosh, P.B. and Saha, T. (2010) Heavy Metal Accumulation in Agricultural Soils around a Coal Fired Thermal Power Plant (Farakka) in India. Journal of Environmental Science and Engineering, 52, 299-306.

[20] Singh, A., Sharma, R.K., Agrawal, M. and Marshall, F.M. (2010) Risk Assessment of Heavy Metal Toxicity through Contaminated Vegetables from Waste Water Irrigated Area of Varanasi, India. Tropical Ecology, 51, 375-387.

[21] Arora, M., Bala, K., Rani, S., Rani, A., Kaur, B. and Mittal, N. (2008) Heavy Metal Accumulation in Vegetables Irrigated with Water from Different Sources. Food Chemistry, 111, 811-815. http://dx.doi.org/10.1016/j.foodchem.2008.04.049

[22] Singh, S., Zacharias, M., Kalpana, S. and Mishra, S. (2012) Heavy Metals Accumulation and Distribution Pattern in Different Vegetable Crops. Journal of Environmental Chemistry and Ecotoxicology, 4, 170-177. http://dx.doi.org/10.5897/JECE11.076

[23] Bhargava, A., Shukla, S., Srivastava, J., Singh, N. and Ohri, D. (2008) Chenopodium: A Prospective Plant for Phytoextraction. Acta Physiologiae Plantarum, 30, 111-120. http://dx.doi.org/10.1007/s11738-007-0097-3

[24] Ramesh, H.L. and Murthy, V.N.Y. (2012) Assessment of Heavy Metal Contamination in Green Leafy Vegetables Grown in Bangalore Urban District of Karnataka. Advances in Life Science and Technology, 6, 40-51.

[25] Radek, M. and Savage, G.P. (2008) Oxalates in Some Indian Green Leafy Vegetables. International Journal of Food Sciences and Nutrition, 59, 246-260. http://dx.doi.org/10.1080/09637480701791176 